This is an Open Access article distributed under the terms of the Creative Commons Attribution 4.0 International License which permits unrestricted non-commercial use, distribution, and reproduction in any medium, provided the original work is properly cited.

http://ijnms.net/index.php/ijnms

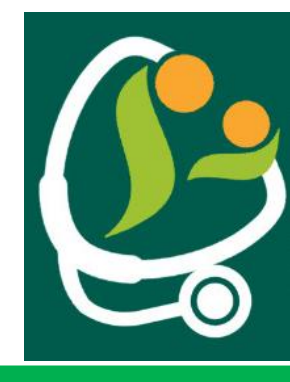

\title{
LONG OF HEMODIALYSIS THERAPY WITH QUALITY LIFE PATIENT FAILS OF KIDNEY CHRONIC IN RS GATOEL MOJOKERTO: STUDY CROSS-SECTIONAL
}

\author{
Arif Wicaksono *, Muhammad Sajidin * \\ *Maternity of Nursing STIKES BINA SEHAT PPNI
}

\section{ABSTRACT}

Keywords

Hemodialysis therapy of patients with chronic kidney disease can changes the patients physically, psychological, social and economics because they have to deal with it for the rest of their life. It can affect the quality of life of the patients because of the long-term of hemodialysis therapy; this is one of the factors that affect the quality of life of the patients with chronic kidney disease. Quality of life is focused on the assessment of the individual against conditions acceptance. Each takes different phases to accept the condition. The purposes of the study were to determine if the relationship between the duration of hemodialysis and quality of life of the patients with chronic kidney disease at Gatoel Hospital Mojokerto. This research used cross-sectional design. The patient's population with chronic kidney disease undergoing hemodialysis is 150 people. The research sample is drawn using sampling techniques with the type of nonprobability purposive sampling with 130 people as a sample. Data obtained from questionnaires KDQoL 36. The result using Spearman rho test using SPSS V.16 shows $p<\alpha(0,006<0,05)$. H0 rejected, this means that there is a relationship between the duration of hemodialysis and quality of life with chronic kidney disease at Gatoel Hospital Mojokerto. The quality of life of the patients fluctuated based on the stage adaptation of the hemodialysis and disease. However, most patients with the duration of hemodialysis for more than 12 months had a sufficient quality of life, and their therapy is already familiar with the symptoms and complications, but other factors affect the quality of life such as gender, marital status, and education level. Patients are also expected to cooperate in what to do and not to do to improve the quality of life of the patients.

Chronic

kidney disease,

Hemodialysis,

Quality of Life 


\section{INTRODUCTION}

Chronic renal failure is a progressive and irreversible kidney function disorder so that patients with chronic renal failure will lose kidney function gradually and can not change. People with chronic renal failure require therapy that aims to support the life of hemodialysis or kidney transplant therapy. For patients with chronic renal failure, hemodialysis therapy should be done throughout life (Muhammad, 2012).

Hemodialysis therapy can prolong unlimited age without clear limits, but this action will not alter the natural course of underlying kidney disease, nor will it restore all kidney function. The patient will still experience some problems and complications from his illness (Brunner \& Suddarth, 2002). Hemodialysis therapy also affects the patient's psychological, social and economic conditions. Patients will experience impaired thinking processes as well as disruptions in social relationships. Not to mention the problem of losing a job, changing family roles, changing relationships and wasted time for dialysis as well as the cost of routinely undergoing hemodialysis. All of these conditions will lead to decreased quality of life for patients with chronic renal failure who undergo hemodialysis therapy (Mailani, 2015).

Indonesia is a country with a high rate of chronic kidney disease, data from health insurance called ASKES in 2010 recorded 17,507 patients, the next year recorded 23,261 and the latest data in 2013 recorded 24,141 patients.(Mailani, 2015). Based on Basic Health Research (Riskesdas) in 2013, it was found that the prevalence and incidence of chronic renal failure in Indonesia was around $0.2 \%$, while in East Java the prevalence and incidence of chronic renal failure was $0.3 \%$.

According to the Indonesian Renal Registry (IRR), new patients undergoing hemodialysis increased from 2011 to 2012, i.e., from
15,353 to 19,621 souls. Of the 19,621 new patients who actively perform hemodialysis, only 9161 souls are dominated by men that are 5.602 and 3,559 inhabitants of women. For total new and old patients who undergo routine hemodialysis in Indonesia as much as 717.497 people while in East Java alone who undergo routine Hemodialysis 97,522 inhabitants.

Referring to Sofiana Nurchayati's (2011) research, the analysis of factors related to the quality of life of chronic kidney disease patients undergoing hemodialysis at Fatimah Islam Hospital Cilacap and Banyumas General Hospital stated that there is a relationship between long hemodialysis with quality of life, $\mathrm{p}=0.035$ ), $\mathrm{OR}=2.637$ which means that respondents who have recently undergone hemodialysis $\leq 11$ months risk 2.6 times less quality life.

Based on Preliminary Study Result on February 25, 2016, in space hemodialysis Gatoel Hospital Mojokerto got the number of normal patients who underwent hemodialysis at Gatoel Hospital amounted to 150 patients. After seven interviews of 10 patients had undergone hemodialysis for more than 11 months, they said they had received all the circumstances that happened to him because he was accustomed to undergoing hemodialysis along with the symptoms and complications of hemodialysis, they said still obediently undergoing hemodialysis to maintain his life. In 3 patients undergoing hemodialysis for less than 11 months, they said they felt more limited life than before, many rules they had to undergo and had to be routinely hospitalized for life-long hemodialysis.

Factors that affect the quality of life in patients undergoing hemodialysis include demographic factors such as age, sex, education, and occupation and other factors that are long undergoing hemodialysis and functional health status (Satvik et al. 2008; Nurchayati 2011). Quality of life is the

International Journal Of Nursing and Midwifery, Volume 1, Issue 1, May-August 2017 
judgment and satisfaction of clients to the level and function of their lives compared to the ideal situation that should be achieved according to the client (Farida, 2010).

Patients who underwent hemodialysis therapy for less than 12 months had a worse quality of life than patients who underwent treatment had been more than 12 months. It is because new patients are still trying to adapt to the conditions they experienced. The longer the patient undergoes hemodialysis, the patient will be more compliant to undergo hemodialysis, as they have reached the stage of receiving and are likely to receive health education from nurses and doctors about illness as well as the importance of regularly performing hemodialysis. (Bestari, 2015).

Based on this background, the researchers are interested to raise the problem of the relationship between long undergoing hemodialysis with the quality of life of patients with chronic renal failure in Gatoel Hospital Mojokerto.

\section{MATERIALS AND METHODS}

This research uses cross-sectional research design that is a type of research which emphasizes time measurement/observation of dependent and independent data variable only one time at one time (Nursalam, 2013). The population is a patient with chronic renal failure who underwent 150 hemodialyses. The sample of this study was taken using nonprobability sampling technique with purposive sampling type of 103 people. With sample criterion in this research consist of:

1. Inclusion Criteria

a. Patients are willing to take the study and sign informed consent.

2. Exclusion Criteria

a. Patients who underwent Hemodialysis $<3$ months.

b. Patients are under 18 years of age

\section{RESULTS}

\section{Frequency Distribution of Respondents} by Sex.

\begin{tabular}{llll}
\hline No & Gender & (f) & Percentage(\%) \\
& & & \\
\hline 1. & Male & 54 & 52,4 \\
2. & Female & 49 & 47,6 \\
\hline Total & & 103 & 100
\end{tabular}

Source: 2016 Data

The table above shows that most of the respondent's male sex as much as 54 people $(52.4 \%)$.

\section{Frequency Distribution of Respondents} by Age

\begin{tabular}{llll}
\hline No. & Age & (f) & Percentage (\%) \\
\hline 1. & $17-25$ & 1 & 1 \\
2. & $26-35$ & 9 & 8,7 \\
3. & $36-45$ & 24 & 23,3 \\
4. & $46-55$ & 41 & 39,8 \\
5. & $56-65$ & 25 & 24,3 \\
6. & $>65$ & 3 & 2,9 \\
& & & \\
\hline Total & & 103 & 100 \\
\hline
\end{tabular}

Source: 2016 Data

The table above shows that almost half respondents aged 46-55 years as many as 41 people $(39.8 \%)$.

\section{Frequency Distribution of Respondents} by Employment Status

\begin{tabular}{llll}
\hline No. & Job status & (f) & Percentage (\%) \\
\hline 1. & work & 29 & 28,2 \\
\hline 2. & unemployment & 74 & 71,8 \\
\hline Total & & 103 & 100
\end{tabular}

Source: 2016 Data

The table above shows that most respondents have not worked as many as 74 people $(71.8 \%)$. 


\section{Frequency Distribution of Respondents} by Marital Status

\begin{tabular}{llll}
\hline No. & Marital Status & (f) & Percentage (\%) \\
\hline 1. & Singel & 3 & 2,9 \\
\hline 2. & Marries & 93 & 90,3 \\
3. & Janda/Duda & 7 & 6,8 \\
\hline Total & & 103 & 100
\end{tabular}

Source: 2016 Data

The table above shows that almost all respondents are married as many as 93 people $(90.3 \%)$.

\section{Distribution of Respondents Frequency} Based on Education Level

\begin{tabular}{llll}
\hline No. & Education Level & (f) & Percentage $(\%)$ \\
\hline 1. & elementary school & 23 & 22,3 \\
\hline 2. & junior high school & 28 & 27,2 \\
& high school & 37 & 35,9 \\
3. & college & 15 & 14,6 \\
4. & & & \\
\hline Total & & 103 & 100
\end{tabular}

Source: 2016 Data

The table above shows that almost half of respondents have high school education level as many as 37 people $(35.9 \%)$.

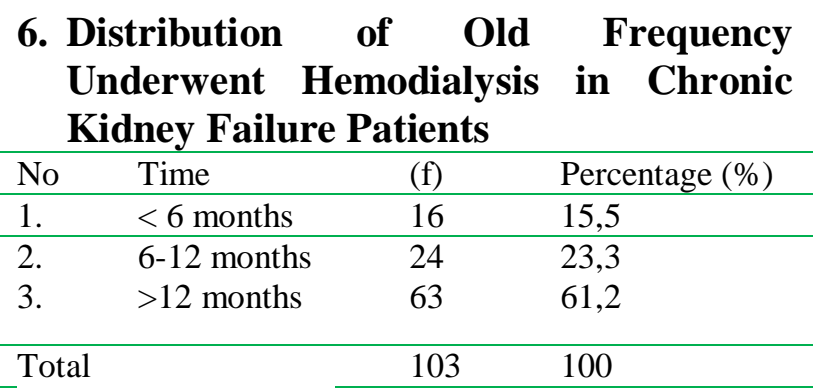

Source: 2016 Data

The table above shows that most respondents undergo hemodialysis over 12 months as many as 63 people $(61.2 \%)$.
7. Distribution of Frequency of Life Quality in Chronic Kidney Failure Patients

\begin{tabular}{llll}
\hline No. & Status & (f) & Percentage $(\%)$ \\
\hline 1. & Good & 17 & 16,5 \\
\hline 2. & Enough & 71 & 68,9 \\
3. & Less & 15 & 14,6 \\
\hline Total & & 103 & 100
\end{tabular}

Source: 2016 Data

The table above shows that most of the respondents have a good quality of life as much as 71 people $(68.9 \%)$.

8. Length of Living Hemodialysis with Quality of Life in Chronic Kidney Failure Patients in Hemodialisa Room of Gatoel Hospital Mojokerto

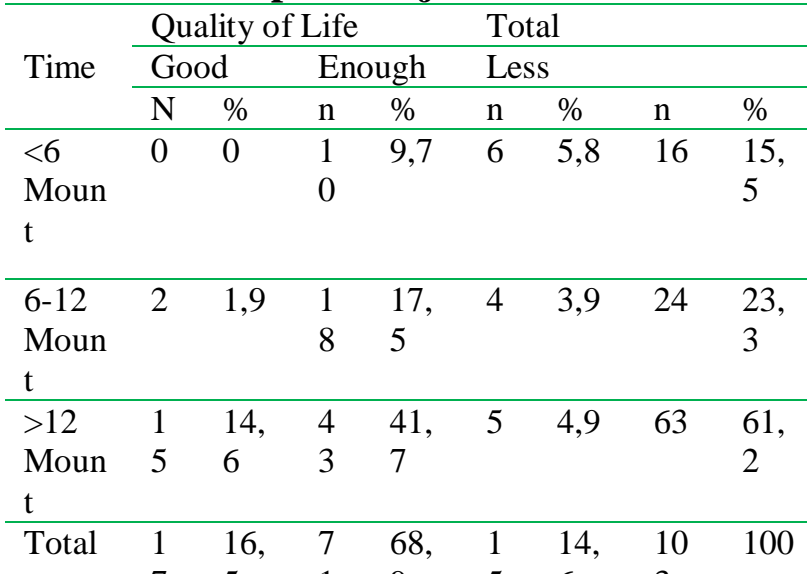

The table above shows that of the 103 respondents in this assessment, most respondents 71 people $(68.9 \%)$ have a quality of life enough that most respondents undergo hemodialysis over 12 months as many as 43 people $(41.7 \%)$.

The result of data calculation by using statistic test of Spearman rho got $p<\alpha$ that is 0,006 $<0,05$ with correlation coefficient 0,267 . So $\mathrm{H} 0$ rejected, and $\mathrm{H} 1$ accepted means that there is a reasonable relationship between long undergoing hemodialysis with the quality of life of patients with chronic renal failure at Gatoel Hospital Mojokerto. 


\section{DISCUSSION}

\section{Long of Hemodialysis therapy}

Table 6 shows that most respondents underwent hemodialysis over 12 months as many as 63 people $(61.2 \%)$.

The length of hemodialysis is the amount of time the respondent has undergone hemodialysis in months (Nurchayati, 2011). Hemodialysis is the replacement of modern kidneys using dialysis to remove undesirable solutes through diffusion and ultrafiltration (O'callaghan, 2009). For patients with chronic renal failure, hemodialysis will prevent death because this therapy is necessary to maintain its survival and control uremia symptoms, so patients with chronic renal failure should undergo lifelong dialysis therapy that lasts three times a week 3-4 hours per therapy (Brunner \&Suddarth, 2002).

Almost all respondents undergo hemodialysis routinely 1-2 times a week for 3-4 hours each time hemodialysis. It is because patients with chronic renal failure who choose hemodialysis therapy should undergo lifelong therapy to support their lives. With hemodialysis therapy, excess fluid and residual metabolism that can not be removed alone by the patient can be removed with a kidney replacement tool. This kidney replacement device works in ultrafiltration, diffusion, and osmosis capable of nephron function in the kidney, so that blood can be filtered by ultrafiltration process, while the rest of metabolism and excess fluid can be excreted through diffusion and osmosis process.

\section{Quality of Life of Chronic Kidney Failure Patients}

Table 7 can be seen that most of the respondents have a good quality of life as much as 71 people $(68.9 \%)$.

Quality of life is defined as the individual perception of their position in life in the context of the culture and value system in which they live and about their standard goals and concerns. This definition reflects the view that quality of life focuses on the quality of life received by respondents, this definition is not expected to provide a way to measure symptoms, disease or conditions with detailed patterns but the effects of disease and health interventions on quality of life (Nursalam, 2013). Factors affecting the quality of life include social demographic factors such as gender, age, education, marital status and education and other factors such as depression, disease stage, hemodialysis duration, hemodialysis education, etc. (Maliani, 2014).

Based on the above theory that many factors affect the quality of life in patients with chronic renal failure. The first factor is gender. Based on table 1 most of the respondents were 54 people $(52.4 \%)$ male. Women tend to have a lower quality of life compared to men. Women tend to be easily stressed with various causes such as estrogen and progesterone hormone instability. Also, appearance is very important for women in general. However, in patients with chronic renal failure physical changes that change a person's self-image becomes less attractive as the color of the skin becomes grayish brown, dry and itchy, thin hair easily falls off and broken and increased weight due to edema. With the physical changes that occur as well as women who are easily stressed will affect the quality of life of patients to be less good.

The second factor affecting the quality of life is the level of education. Based on table 5 almost half of the respondents have high school education level as many as 37 people (35.9\%). Patients with higher education will have a broader knowledge that allows selfmastery in the face of problems, easy to understand what is recommended by health workers and can reduce anxiety that can help the individual in making decisions (Dewi, 2015). Patients with higher education have extensive knowledge that can influence 
positive attitudes and behaviors so that patients can accept the conditions they feel. Acceptance is at the core of the quality of life assessment, individuals who have received will tend to have a good quality of life.

The third factor affecting the quality of life is marital status. Based on table 4 almost all respondents are married as many as 93 people $(90.3 \%)$. Whether or not the support received from a partner by patients with chronic renal failure is crucial to the course of the disease and the availability of therapy. Support can be motivation, reward, attention and give solution (Putri, 2014). With the support of a spouse, patients with chronic renal failure can experience emotional changes such as feeling cared for and more enthusiastic to live life. This emotional change can change the course of the disease in a better direction so that the quality of life of the patient can be better.

\section{Long Live Hemodialysis with Quality of Life of Chronic Kidney Failure Patients at Gatoel Hospital Mojokerto}

The result of Spearman rho statistic test got $\mathrm{p}$ $<\alpha$ that is $0,006<0,05$. So $\mathrm{H} 0$ rejected, and $\mathrm{H} 1$ accepted means that there is a relationship between long undergoing hemodialysis with the quality of life of patients with chronic renal failure in Gatoel Hospital Mojokerto.

This is in accordance with Bestari's (2015) theory that long undergoing hemodialysis affects the quality of life of chronic renal failure patients undergoing hemodialysis. Patients undergoing hemodialysis for more than 12 months have reached the long-term adaption stage after one year of Hemodialysis therapy. Usually, patients are accustomed to receiving limitations and complications (Hawari, 2001; Arifin, 2010)

The long duration of hemodialysis therapy has an influence on the quality of life. Each patient needs different amounts of time to adapt to the changes he or she encounters such as life-threatening symptoms, complications, and therapies. This the quality of life in patients with chronic renal failure also fluctuates according to the time required for each stage of adaptation to hemodialysis therapy. However, the majority of respondents who undergo hemodialysis over 12 months have an adequate quality of life because the longer the patient undergoes hemodialysis then the patient will be accustomed and receive all the symptoms and complications. Patients who can accept the condition well then it will have a good quality of life as well because the quality of life focused on the acceptance of respondents to the conditions he felt.

Table 8 shows that respondents who undergo hemodialysis less than 6 months have enough quality of life as many as 10 people $(9.7 \%)$ and quality of life is less than 6 people $(5.8 \%)$.

According to Hawari (2001) in Arifin (2010), Chronic Kidney Failure patients undergoing Hemodialysis therapy undergo several adaptation stages. In the first period of the honeymoon period which begins the first week of Hemodialysis up to 6 months, where patients still receive dependence Hemodialysis machine, still, have the confidence and appreciation. According to Bestari (2015), the quality of life is also influenced by the experience, belief, expectation, and perception of the person so that the quality of life is more subjective that assess their position in life.

According to the above theory in the honeymoon period, patients who can still receive dependence Hemodialisa machine can have a quality of life is quite even good. Because of the quality of life that focuses on the individual's perception of the acceptance of the conditions in his or her life. However, in 6 people $(5.8 \%)$ who underwent hemodialysis less than 6 months had a poor quality of life. Judging from the 5 domains of quality of life, that the majority of 6 
respondents have a low physical domain value so as to have a poor quality of life. This condition is caused because one of the effects of chronic kidney failure disease is the physical changes of respondents. Physical changes that often occur in patients with chronic renal failure among others, weakness, nausea, vomiting, edema, shortness of breath, extremity pain, dizziness, etc. So the ability of respondents to move to be limited.

Table 4 shows that respondents who undergo hemodialysis 6-12 months have a good quality of life 2 people (1.9\%), quality of life is enough as much 18 people $(17,5 \%)$ and quality of life is less than 4 people $(3,9 \%)$.

According to Hawari (2001) in Arifin (2010), the next period is the period of disenchantment - discouragement (i.e., discouragement) that is after 6 months to 12 months of Hemodialysis therapy, this is characterized by changes in stress behavior. Good quality of life can be characterized freely by disease complaints, normal body function, healthy and happy feelings, satisfactory work, good interpersonal relationships and good ability to deal with stress in life (Bestari, 2015).

The above theory in the period of disenchantment - discouragement of patients showed changes in stress behavior that will affect the quality of life of patients to be less good. But it is different in 2 people $(1.9 \%)$ who have a good quality of life and 18 people $(17.5 \%)$ who have enough quality of life. Judging from other factors that affect the quality of life such as marital status and social support, that the majority of these 2 persons and 18 persons are married and get positive support from families and health workers. With the abundance of support provided, patients will be able to establish good interpersonal relationships. The relationship can reduce the stress he felt by telling the feelings felt to the people closest. In addition, the role of health workers who are acting as counselors, educators, advocates and direct treatment can prevent complications from the disease that affects the quality of life of respondents to be better.

Table 4 shows that respondents who undergo hemodialysis over 12 months have a good quality of life as many as 15 people (14.6\%), quality of life is quite as much as 43 people $(41.7 \%)$ and quality of life is less as much as 5 people $(4.9 \%)$.

According to Hawari (2001) in Arifin (2010), the last period is the period of longterm adaption (advanced adaptation), ie after one year of Hemodialisa therapy. Usually, patients have started accustomed to accepting limitations and complications. According to Nursalam (2013), the quality of life is defined as the perception of individuals in their position in life because the quality of life is focused on the quality of life received by individuals.

The above theory in the long-term adaption period, patients tend to have an adequate quality of life for the good quality of life because patients are able to accept limitations due to symptoms and complications of disease and hemodialysis therapy. However, it was different in 5 respondents $(4.9 \%)$ who underwent hemodialysis over 12 months had a poor quality of life. This happens because there are other factors that affect the quality of life such as age. The majority of 5 respondents have entered the age of the initial elderly, which occurs the process of decreased organ function that can aggravate the course of disease and complications. The more symptoms and complications felt by respondents will be less the quality of life.

\section{CONCLUSIONS}

1. Long hemodialysis in patients with chronic renal failure in the Hemodialisa Room of Gatoel Hospital Mojokerto, most respondents undergo hemodialysis more 
than 12 months as many as 63 people $(61.2 \%)$.

2. Quality of life in patients with chronic renal failure in Hemodialisa Room RS GatoelMojokerto, most of the respondents have a good quality of life as much as 71 people $(68.9 \%)$.

3. There is a relationship between long undergoing hemodialysis with the quality of life of patients with chronic renal failure in RS GatoelMojokerto in accordance with Spearman rho statistical test, obtained $\mathrm{p}<\alpha$ that is $0.006<0.05$.

\section{REFERENCES}

Arifin,N.(2010). AnalisisFaktor-Faktor yang Berhubungandengan Tingkat KecemasanPasienGagalGinjal Terminal SelamaMenjalaniTerapiHemodialisis di BadanPelayananKesehatan RSU Tidar Kota Magelang. Diambildari JTPTUNISMU

http://digilib.unimus.ac.id

Arikunto, S. (2013). ProsedurPenelitian. Jakarta :RenekaCipta.

Baradero, M., Dayrit, M. W., \& Siswadi, Y. (2009). Klien Gangguan Ginjal: Seri Asuhan Keperawatan. Jakarta: EGC.

Brunner \& Suddarth. (2002). Buku Ajar Keperawatan Medikal Bedah Edisi 8 Volume 2. Jakarta: EGC

Bestari, A.W. (2015). Faktor yang berhubungan dengan Kualitas Hidup Pasien Gagal Ginjal Kronik yang menjalani Heodialisis. Diambil dari adln.lib.unair.ac.id/gdlhub-gdl-sl2015-bestariani-41071-7.pdf

Dewi, S. P. (2015). Hubungan Lamanya Hemodialisis dengan Kualitas Hidup Pasien Gagal Ginjal di RS PKU
Muhammadiyah Yogyakarta. Diambil dari HYPERLINK "http://opac.say.ac.id/id/eprint/234" http://opac.say.ac.id/id/eprint/234

Farida, A. (2010). Pengalaman Klien Hemodialisis Terhadap Kualitas Hidup Dalam Konteks Asuhan Keperawatan di RSUP Fatmawati Jakarta. Diambil dari $\underline{\text { lib.ui.ac.id/file?file=digital/137288-T- }}$ Anna\%20Farida.pdf

Chang, E, dkk. (2010). Patofisiologi Aplikasi pada Praktik Keperawatan. Jakarta: EGC

Harrison. (2013). Nefrologi dan Gangguan Asam-Basa. Jakarta: EGC. .(2013). Buku Saku Nefrologi Disertai Contoh Kasus. Tangerang: KARISMA.

Hastono, S.P. \& Sabri, L. (2010). Statistika Kesehatan. Jakarta: Rajawali Pers

Hays R.D., Kallich J. D., Mapes D. L., Coons S. J., Carter W. B. (1994). Development of the kidney disease quality of life (KDQOL) instrument. Qual Life Res 1994, Oct;3(5):329-38

Hidayat, A. A. A.Mailani, F. (2015). Kualitas Hidup Pasien Penyakit Ginjal Kronik yang Menjalani Hemodialisis: Systematic Review. Ners Jurnal Keperawatan , 1-8.

Muhammad, A. (2012). Serba Serbi Gagal Ginjal. Jogjakarta: DIVA Press.KARISMA Publishing Group.

Notoatmodjo, S. (2012). Metode Penelitian Kesehatan. Jakarta: Rineka Cipta.

Nurarif, A. H., \& Kusuma, H. (2015). Aplikasi Asuhan Keperawatan Berdasarkan Diagnosa Medis \& NANDA NIC-NOC. Jogjakarta: MediAction publishing. 
Nurchayati, S. (2011). Analisis Faktor-Faktor yang Berhubungan dengan Kualitas Hidup Pasien Penyakit Ginjal Kronik yang Menjalani Hemodialisis di Rumah Sakit Islam Fatimah Cilacap dan Rumah Sakit Umum Daerah Banyumas. Diambil dari lontar.ui.ac.id

Nursalam. (2013). Metode Penelitian Ilmu Kesehatan. Jakarta : Salemba Medika.

O'Callaghan, C. (2009). At a Glance Sistem Ginjal Edisi ke Dua. Jakarta: Erlangga.

Putri, R. (2014). Gambaran Kualitas Hidup Pasien Gagal Ginjal Kronik yang Menjalani Terapi Continuous Ambulatory Peritoneal Dialysis di RSUD Arifin Achmad Provinsi Riau dengan Menggunakan Kuesioner KDQOL-SF.

Riwidikdo, H. (2009). Statistik Kesehatan Belajar Mudah Teknik Analisa Data dalam Penelitian Kesehatan (Plus Aplikasi Software SPSS). Jogjakarta: Mitra Cendikia Press.

Rachmawati, S. (2013). Kualitas Hidup Orang Dengan Hiv/Aids Yang
Mengikuti Terapi Antiretroviral. Jurnal SAINS Dan Praktik Psikologi, 50 .

Schatell, D., \& Witten, B. (2012). Measuring Dialysis Patient's Health-Related Quality of Life with KDQOL-36 ${ }^{T M}$. Medical Education Institute

Setiadi. (2013). KonsepdanPraktikPenulisanRisetKepe rawatanEdisi 2. Yogyakarta: Grahallmu.

Sugiyono. (2013). MetodePenelitian Pendidikan. Bandung: Alfabeta.

Supriyadi, dkk. (2011). Tingkat Kualitas Hidup Gagal Ginjal Kronik Terapi Hemodialisa. Jurnal Kesehatan Masyarakat, 107-112.

Thaweethamcharoen et al. (2013). PatientReported Outcomes (Pro) Or Quality Of Life (QoL) Studies Validity And Reliability of Kdqol-36 In Thai Kidney Disease Patient. Value in health regional issue 3: 98-102 